\title{
Challenge Testing the Lactoperoxidase System Against a Range of Bacteria Using Different Activation Agents
}

\author{
L. W. T. Fweja, M. J. Lewis, and A. S. Grandison ${ }^{1}$ \\ Department of Food Biosciences, University of Reading, Whiteknights, Reading RG6 6AP, United Kingdom
}

\begin{abstract}
Lactoperoxidase (LP) exerts antimicrobial effects in combination with $\mathrm{H}_{2} \mathrm{O}_{2}$ and either thiocyanate $\left(\mathrm{SCN}^{-}\right)$ or a halide (e.g., $\mathrm{I}^{-}$). Garlic extract in the presence of ethanol has also been used to activate the LP system. This study aimed to determine the effects of $3 \mathrm{LP}$ activation systems $\left(\mathrm{LP}+\mathrm{SCN}^{-}+\mathrm{H}_{2} \mathrm{O}_{2} ; \mathrm{LP}+\mathrm{I}^{-}+\mathrm{H}_{2} \mathrm{O}_{2} ; \mathrm{LP}+\right.$ garlic extract + ethanol) on the growth and activity of 3 test organisms (Staphylococcus aureus, Pseudomonas aeruginosa, and Bacillus cereus). Sterilized milk was used as the reaction medium, and the growth pattern of the organisms and a range of keeping quality (KQ) indicators $(\mathrm{pH}$, titratable acidity, ethanol stability, clot on boiling) were monitored during storage at the respective optimum growth temperature for each organism. The $\mathrm{LP}+\mathrm{I}^{-}+\mathrm{H}_{2} \mathrm{O}_{2}$ system reduced bacterial counts below the detection limit shortly after treatment for all 3 organisms, and no bacteria could be detected for the duration of the experiment ( 35 to $55 \mathrm{~h}$ ). The KQ data confirmed that the milk remained unspoiled at the end of the experiments. The LP + garlic extract + ethanol system, on the other hand, had no effect on the growth or KQ with $P$. aeruginosa, but showed a small retardation of growth of the other 2 organisms, accompanied by small increases ( 5 to $10 \mathrm{~h}$ ) in $\mathrm{KQ}$. The effects of the $\mathrm{LP}+\mathrm{SCN}^{-}+\mathrm{H}_{2} \mathrm{O}_{2}$ system were intermediate between those of the other 2 systems and differed between organisms. With $P$. aeruginosa, the system exerted total inhibition within $10 \mathrm{~h}$ of incubation, but the bacteria regained viability after a further $5 \mathrm{~h}$, following a logarithmic growth curve. This was reflected in the KQ indicators, which implied an extension of $15 \mathrm{~h}$. With the other 2 bacterial species, $\mathrm{LP}+\mathrm{SCN}^{-}+\mathrm{H}_{2} \mathrm{O}_{2}$ exerted an obvious inhibitory effect, giving a lag phase in the growth curve of 5 to $10 \mathrm{~h}$ and $\mathrm{KQ}$ extension of 10 to 15 $\mathrm{h}$. When used in combination, $\mathrm{I}^{-}$and $\mathrm{SCN}^{-}$displayed negative synergy.
\end{abstract}

Received April 30, 2007.

Accepted March 4, 2008.

${ }^{1}$ Corresponding author: a.s.grandison@reading.ac.uk
Key words: challenge testing, lactoperoxidase, antimicrobial effect, keeping quality

\section{INTRODUCTION}

Lactoperoxidase $(\mathbf{L P})$ exerts antimicrobial effects when combined with a source of $\mathrm{H}_{2} \mathrm{O}_{2}$ and either thiocyanate $\left(\mathbf{S C N}^{-}\right)$or a halide. The enzyme can also catalyze the oxidation of sulfur compounds in garlic, at the expense of oxygen released from ethanol, to generate antimicrobial products (Jandal, 1998). The enzyme together with a source of $\mathrm{H}_{2} \mathrm{O}_{2}$ /oxygen and an electron donor form the LP system (LP-s). The system has wide applications in the dairy industry, particularly in raw milk preservation in situations where prompt refrigeration is difficult, especially in developing countries. Activation of the LP-s can be used to extend the keeping quality (KQ) before heat treatment.

Different activation strategies and substrate levels have been used in earlier studies to activate the $\mathrm{LP}+\mathrm{SCN}^{-}+\mathrm{H}_{2} \mathrm{O}_{2}$ system. Siva et al. (1991) reported extended $\mathrm{KQ}$ of $9.9,12.2$, and $13.6 \mathrm{~h}$ of raw milk treated with equal concentrations of 10:10, 20:20, and 30:30 $\mathrm{mg} / \mathrm{kg}$ of $\mathrm{SCN}^{-}: \mathrm{H}_{2} \mathrm{O}_{2}$, respectively, at a storage temperature of $30^{\circ} \mathrm{C}$. With an excessive molar concentration of $\mathrm{H}_{2} \mathrm{O}_{2}$, Ewais et al. (1985) reported a $\mathrm{KQ}$ of $48 \mathrm{~h}$ for buffalo and cow milk preserved at 20 to $22^{\circ} \mathrm{C}$, and treated with 10:25 and 10:30 mg/kg of $\mathrm{SCN}^{-}: \mathrm{H}_{2} \mathrm{O}_{2}$. However, they reported that a greater concentration of $\mathrm{H}_{2} \mathrm{O}_{2}$ was necessary for preservation of milk at temperatures as high as $35^{\circ} \mathrm{C}$. The use of 70 to $80 \mathrm{mg} / \mathrm{kg}$ of $\mathrm{H}_{2} \mathrm{O}_{2}$ at that temperature kept the acidity of milk unchanged for $24 \mathrm{~h}$ and greater levels of $\mathrm{H}_{2} \mathrm{O}_{2}(>80 \mathrm{mg} / \mathrm{kg})$ further extended the $\mathrm{KQ}$ of buffalo and cow milk. Barraquio et al. (1994) reported a 7-h extended shelf life in LP-s activated raw milk treated with $14: 30 \mathrm{mg} / \mathrm{kg}$ of $\mathrm{SCN}^{-}: \mathrm{H}_{2} \mathrm{O}_{2}$ at 27 to $32^{\circ} \mathrm{C}$ ambient temperature. On using excess molar concentration of $\mathrm{SCN}^{-}, 15: 10 \mathrm{mg} / \mathrm{kg}$ of $\mathrm{SCN}^{-}: \mathrm{H}_{2} \mathrm{O}_{2}$, Chakraborty et al. (1986) recorded a 3$\mathrm{h}$ extension in shelf life of buffalo milk at $37^{\circ} \mathrm{C}$, and Björck et al. (1979) reported the total lag phase of 7 to $8 \mathrm{~h}\left(30^{\circ} \mathrm{C}\right), 11$ to $12 \mathrm{~h}\left(25^{\circ} \mathrm{C}\right), 15$ to $16 \mathrm{~h}\left(20^{\circ} \mathrm{C}\right)$, and 24 to $26 \mathrm{~h}\left(15^{\circ} \mathrm{C}\right)$ using $10: 8.5 \mathrm{mg} / \mathrm{kg}$ of $\mathrm{SCN}^{-}: \mathrm{H}_{2} \mathrm{O}_{2}$. CailliezGrimal et al. (2002) observed increased antimicrobial 
activity of the LP-s associated with greater bacterial inhibition when $\mathrm{SCN}^{-}$was replaced with $\mathrm{I}^{-}$or $\mathrm{IO}^{3-}$. Similarly, Revol-Junelles et al. (2001) reported that activation with $\mathrm{I}^{-}$or $\mathrm{IO}^{3-}$ gave greater, permanent inhibition of gram-positive bacteria, particularly Staphylococcus aureus at 25 and $15^{\circ} \mathrm{C}$, than $\mathrm{SCN}^{-}$. However, no antibacterial action was observed against gram-negative strains. Jandal (1998) activated the LP-s with garlic extract + ethanol $(\mathrm{GE}+\mathrm{E})$ in raw buffalo milk stored at ambient temperature $\left(25^{\circ} \mathrm{C}\right)$, which resulted in an increased storage life of up to $15 \mathrm{~h}$ based on titratable acidity, $9 \mathrm{~h}$ based on alcohol stability, and $15 \mathrm{~h}$ based on clot on boiling. Although extensive work has been done on the preservation of raw cow milk using $\mathrm{LP}+\mathrm{SCN}^{-}+\mathrm{H}_{2} \mathrm{O}_{2}$, the $\mathrm{LP}+\mathrm{I}^{-}+\mathrm{H}_{2} \mathrm{O}_{2}$ system is less well understood, and no systematic study has been carried out $\mathrm{LP}+\mathrm{GE}+\mathrm{E}$ systems. The aim of this work was to investigate the influence of the different substrates of the LP-s on antimicrobial activity by challenge testing against bacteria of importance to milk spoilage, and to assess the relative performance of the system on milk preservation. The test organisms used were Staph. aureus, Pseudomonas aeruginosa, and Bacillus cereus. Ultra-high temperature sterilized and raw whole cow milk were used as reaction media. It should be noted that LP activity is completely destroyed by the UHT treatment, and hence enzyme had to be added to UHT milk in these experiments. Growth pattern and keeping quality indicators were used to measure the antimicrobial activities of the $\mathrm{LP}+\mathrm{SCN}^{-}+\mathrm{H}_{2} \mathrm{O}_{2}, \mathrm{LP}+\mathrm{I}^{-}+\mathrm{H}_{2} \mathrm{O}_{2}$, and $\mathrm{LP}+\mathrm{GE}+\mathrm{E}$ systems.

\section{MATERIALS AND METHODS}

\section{Materials}

Sodium percarbonate $\left(\mathrm{Na}_{2} \mathrm{CO}_{3} \cdot 1 \cdot 5 \mathrm{H}_{2} \mathrm{O}_{2}\right)$ was used as a source of $\mathrm{H}_{2} \mathrm{O}_{2}$ for LP system activation; $\mathrm{SCN}^{-}$was in the form of NaSCN and $\mathrm{I}^{-}$in the form of KI (all supplied by Sigma-Aldrich, Gillingham, UK). Bovine LP was kindly donated by DMV International (New York, NY).

Homogenized whole UHT milk was supplied by Arla Foods (Leeds, UK). This milk was used because it is sterile, thereby minimizing or avoiding contamination with microorganisms other than the test organisms.

\section{Test Organisms and Growth Conditions}

Three strains, Staph. aureus (NCDO 10651), P. aeruginosa (NCTC 10299), and B. cereus (NCDO 0577) obtained from the departmental stock culture maintained at $-80^{\circ} \mathrm{C}$ in cryoprotective media, were used in this study. The cultures were selected on the basis that they have the potential to cause spoilage in raw and pasteurized products. Cultures were regenerated in nutrient broth and grown overnight on nutrient agar slants at $30^{\circ} \mathrm{C}$. Single colonies were isolated from stock slants by streaking onto agar plates at $30^{\circ} \mathrm{C}$ for $24 \mathrm{~h}$, and the purity of the test organisms was confirmed by microscopic examination. Working inocula for antibacterial assays were prepared by subculturing single colonies from agar plate streaks into nutrient broth and incubating at the optimum growth temperatures of the organisms: $25^{\circ} \mathrm{C}\left(P\right.$. aeruginosa) $37^{\circ} \mathrm{C}$ (Staph. aureus), and $30^{\circ} \mathrm{C}$ (B. cereus) for 18 to $20 \mathrm{~h}$. The number of viable cells was around $10^{7}$ to $10^{8} \mathrm{cfu} / \mathrm{mL}$ of broth.

\section{Preparation of the LP+GE+E System Substrates}

Garlic was skinned and the central part ground in a sterile mortar. The resulting concentrated extract was first filtered through muslin cloth and then through Whatman filter paper no. 4. The concentrated garlic extract filtrate was diluted ( $1 \% \mathrm{vol} / \mathrm{vol})$ in distilled water. Each $1 \mathrm{~mL}$ of $1 \%$ garlic extract combined with 1 $\mathrm{mL}$ of $1 \%$ ethanol was considered to be equivalent to $10 \mathrm{mg} / \mathrm{kg}$ as claimed previously by Jandal (1998).

\section{Activation of the Different LP-s}

The concentration of LP used was $30 \mathrm{mg} / \mathrm{kg}$, based on its natural concentration in milk (De Wit and Van Hooydonk, 1996). The $\mathrm{H}_{2} \mathrm{O}_{2}$ concentration of $80 \mathrm{mg} / \mathrm{kg}$ was adopted in this study because the findings of Ewais et al. (1985) demonstrated effective performance of the $\mathrm{LP}+\mathrm{SCN}^{-}+\mathrm{H}_{2} \mathrm{O}_{2}$ system with $\mathrm{H}_{2} \mathrm{O}_{2}$ concentrations of 70 to $80 \mathrm{mg} / \mathrm{kg}$, ensuring an extended shelf life of $24 \mathrm{~h}$. The recommended $\mathrm{SCN}^{-}$level is between 3.5 and 12 $\mathrm{mg} / \mathrm{kg}$ (Rossi and De Oliveira, 1993-1994) or $\leq 10 \mathrm{mg} /$ $\mathrm{kg}$ (Ewais et al., 1985). Therefore, the concentration of $7: 80 \mathrm{mg} / \mathrm{kg}$ of $\mathrm{SCN}^{-}: \mathrm{H}_{2} \mathrm{O}_{2}$ was chosen to activate the LP system in these experiments. For comparison, the same substrate level was adopted for $\mathrm{LP}+\mathrm{I}^{-}+\mathrm{H}_{2} \mathrm{O}_{2}$ system; that is, $7: 80 \mathrm{mg} / \mathrm{kg}$ of $\mathrm{I}^{-}: \mathrm{H}_{2} \mathrm{O}_{2}$. Substrates for the $\mathrm{LP}+\mathrm{GE}+\mathrm{E}$ system were similarly established based on earlier work (Jandal, 1998), and preliminary trials in raw milk (data not shown) gave the best KQ for 110:30 $\mathrm{mg} / \mathrm{kg}$ garlic extract:ethanol combination level.

The composition of the reaction mixtures for the different LP-s were as follows: $\mathrm{LP}+\mathrm{SCN}^{-}+\mathrm{H}_{2} \mathrm{O}_{2}(30: 7: 80$ $\mathrm{mg} / \mathrm{kg}), \mathrm{LP}+\mathrm{I}^{-}+\mathrm{H}_{2} \mathrm{O}_{2}(30: 7: 80 \mathrm{mg} / \mathrm{kg})$, and $\mathrm{LP}+\mathrm{GE}+\mathrm{E}$ $(30: 110: 30 \mathrm{mg} / \mathrm{kg})$.

Lactoperoxidase, thiocyanate, iodide, and sodium percarbonate were dissolved separately in $1 \mathrm{~mL}$ of HPLC water and subsequently added to whole UHT milk (inoculated with test strains) individually through syringe filters. 


\section{Determination of Antimicrobial Activity}

To determine the antimicrobial activity of the different LP-s, UHT milk ( $2 \mathrm{~L}$ ) was inoculated with pure cultures of the test bacteria to give an initial concentration of approximately $10^{2} \mathrm{cfu} / \mathrm{mL}$. The milk was thoroughly agitated for $5 \mathrm{~min}$ to ensure uniform suspension of the bacteria and then divided into 4 subsamples. The LP-s for 3 subsamples were activated using different substrates as described above and the untreated subsample was used as a control. After thorough mixing, all samples were aliquoted (25-mL samples) into 30 $\mathrm{mL}$ sterile containers and incubated at each culture's respective optimum growth temperatures: $25^{\circ} \mathrm{C}(P$. aeruginosa), $37^{\circ} \mathrm{C}$ (Staph. aureus), and $30^{\circ} \mathrm{C}$ (B. cereus). The growth pattern was followed and the KQ determined. Samples were taken at $0 \mathrm{~h}$ (just after inoculation) and at 5-h intervals and the total viable count (TVC) of surviving cells was determined by the surface plate agar method as described previously (Marks et al., 2001). The TVC was determined using $0.1 \mathrm{~mL}$ of the required dilution $\left(10^{0}\right.$ to $10^{5}$ serial dilutions $)$ on predried and appropriately marked duplicate Petri plates (plate count agar CM183, Oxoid Ltd., Basingstoke, UK) with sterile spreaders. The plates were incubated in an inverted position for $48 \mathrm{~h}$ and the colonies counted promptly after the incubation period. The TVC measurements were aimed at monitoring the growth pattern of the bacteria and relate to the antibacterial effects of the different LP systems.

\section{Determination of $K Q$}

Keeping quality of whole UHT milk inoculated with pure cultures of the test bacteria, activated with the appropriate systems and incubated at their respective optimum temperatures, was measured using $\mathrm{pH}$, titratable acidity, clot on boiling, and alcohol stability tests as described below. All KQ measurements were carried out in duplicate.

For titratable acidity, $1 \mathrm{~mL}$ of phenolphthalein solution $(0.5 \% \mathrm{wt} / \mathrm{wt})$ was added to $10 \mathrm{~mL}$ of milk. The mixture was titrated against $0.11 M \mathrm{NaOH}$ (VWR International Ltd., Poole, UK) to an end point marked by a pink color persistent for at least $5 \mathrm{~s}$. The milk was judged to be spoiled when TA had increased by $0.02 \%$ (Chakraborty et al., 1986).

The clot on boiling test was performed by boiling 2 $\mathrm{mL}$ of milk sample in a test tube for $5 \mathrm{~min}$, after which it was examined for curdling by tilting the tube gently. The sample was judged to be spoiled when clotting was observed (Harding, 1995).

For the alcohol stability test, equal volumes of milk and $70 \%$ ethanol (prepared from 99\% ethanol, VWR International Ltd.) were mixed in a test tube. The tube

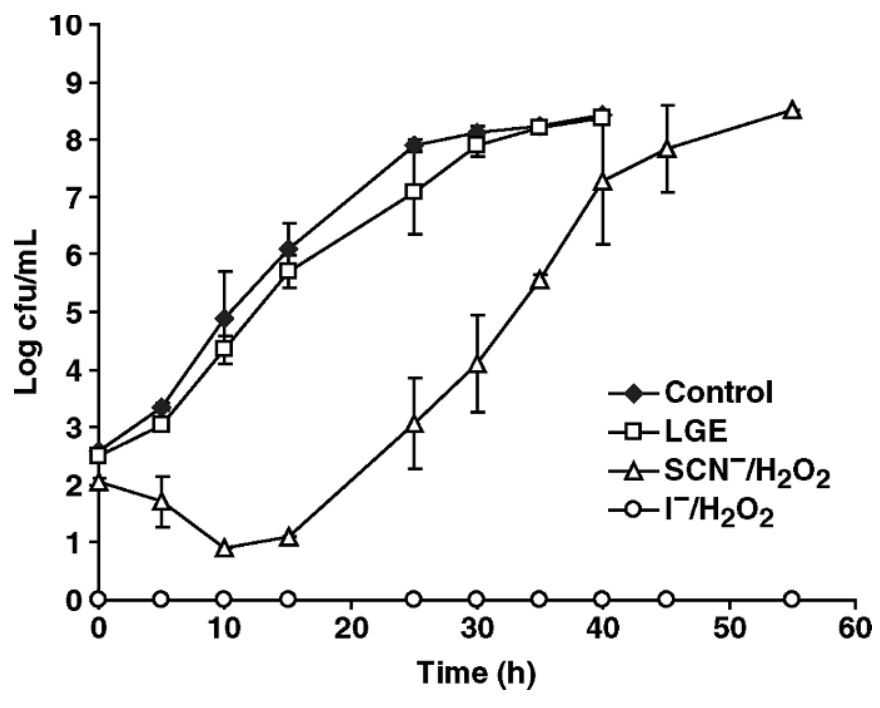

Figure 1. The antimicrobial effects of the different lactoperoxidase (LP) systems against Pseudomonas aeruginosa in whole UHT milk. Error bars show the range of data from 2 separate experiments (detection limit $=1 \log \mathrm{cfu} / \mathrm{mL}$ ). Systems: $\mathrm{LGE}=\mathrm{LP}+$ garlic extract + ethanol; $\mathrm{SCN}^{-} / \mathrm{H}_{2} \mathrm{O}_{2}=\mathrm{LP}+$ thiocyanate + hydrogen peroxide; $\mathrm{I}^{-} /$ $\mathrm{H}_{2} \mathrm{O}_{2}=\mathrm{LP}+$ iodide + hydrogen peroxide.

was inverted several times and then examined for coagulation. Coagulation of milk indicated spoilage (Marks et al., 2001).

The $\mathrm{pH}$ was determined with a $\mathrm{pH}$ meter (ABB Kent EIL 7045/46, Kent, UK) and spoilage was judged to have occurred by a decrease in $\mathrm{pH}$ of 0.4 units (Barrett et al., 1999).

There was generally very good agreement between the 4 methods of $\mathrm{KQ}$ assessment, and hence to simplify presentation, $\mathrm{KQ}$ is summarized as the range of values of time for spoilage to occur over the 4 methods in duplicate experiments.

\section{RESULTS}

\section{Antimicrobial Effects of the LP-s}

This series of experiments was designed to measure the antibacterial effect of the $3 \mathrm{LP}$-s. Two parameters, bacterial viability of $P$. aeruginosa, Staph. aureus, and B. cereus, and KQ of the respective samples, were employed as measures of the antibacterial effects of the different LP systems. The experiments were carried out in duplicate on separate dates.

Figure 1 shows the differences in susceptibility of $P$. aeruginosa to the different $\mathrm{LP}$ systems. The $\mathrm{LP}+\mathrm{I}^{-}$ $+\mathrm{H}_{2} \mathrm{O}_{2}$ system reduced the bacterial counts to below the detection limit (log $\mathrm{cfu} / \mathrm{mL}=1$ ) just after treatment. No counts were detected up to the end of the experiment, which suggests a rapid and complete inactivation 
Table 1. The keeping quality of whole UHT milk inoculated with Staphylococcus aureus, Bacillus cereus, or Pseudomonas aeruginosa, and preserved by activation of lactoperoxidase (LP) systems using different substrates ${ }^{1}$

\begin{tabular}{lccc}
\hline & \multicolumn{3}{c}{ Keeping quality $(\mathrm{h})$} \\
\cline { 2 - 4 } Preservation $_{\text {treatment }}$ & P. aeruginosa & Staph. aureus & B. cereus \\
\hline Control & $25-30$ & $25-30$ & $15-25$ \\
$\mathrm{LP}+\mathrm{GE}+\mathrm{E}$ & $25-30$ & $30-35$ & $25-30$ \\
$\mathrm{LP}+\mathrm{SCN}+\mathrm{H}_{2} \mathrm{O}_{2}$ & $40-45$ & $35-40$ & $30-35$ \\
$\mathrm{LP}+\mathrm{I}^{-}+\mathrm{H}_{2} \mathrm{O}_{2}$ & $>55$ & $>45$ & $>35$ \\
\hline
\end{tabular}

${ }^{1} \mathrm{LP}+\mathrm{GE}+\mathrm{E}=\mathrm{LP}+$ garlic extract + ethanol; $\mathrm{LP}+\mathrm{SCN}^{-}+\mathrm{H}_{2} \mathrm{O}_{2}=$ $\mathrm{LP}+$ thiocyanate + hydrogen peroxide; $\mathrm{LP}+\mathrm{I}^{-}+\mathrm{H}_{2} \mathrm{O}_{2}=\mathrm{LP}+$ iodide + hydrogen peroxide.

of the strain. The effect of the $\mathrm{LP}+\mathrm{SCN}^{-}+\mathrm{H}_{2} \mathrm{O}_{2}$ was time dependent. The system exerted complete bacterial inhibition within a 10-h incubation period, but the bacteria regained viability $5 \mathrm{~h}$ later. There was little effect on bacterial viability and growth with the $\mathrm{LP}+\mathrm{GE}+\mathrm{E}$ system. The KQ (Table 1) of the $\mathrm{LP}+\mathrm{GE}+\mathrm{E}$ treated sample was comparable to that of the control, implying no increase in shelf life. The $\mathrm{LP}+\mathrm{SCN}^{-}+\mathrm{H}_{2} \mathrm{O}_{2}$ system extended the KQ by $15 \mathrm{~h}$, whereas the $\mathrm{LP}+\mathrm{I}^{-}+\mathrm{H}_{2} \mathrm{O}_{2}$ sample had a $\mathrm{KQ}$ more than $10 \mathrm{~h}$ longer than the former system, and the milk was unspoiled at the end of the experiment.

The $\mathrm{LP}+\mathrm{I}^{-}+\mathrm{H}_{2} \mathrm{O}_{2}$ system showed similar lethal effects on Staph. aureus (Figure 2) as on P. aeruginosa. However, the reduction of counts to below the detection limit

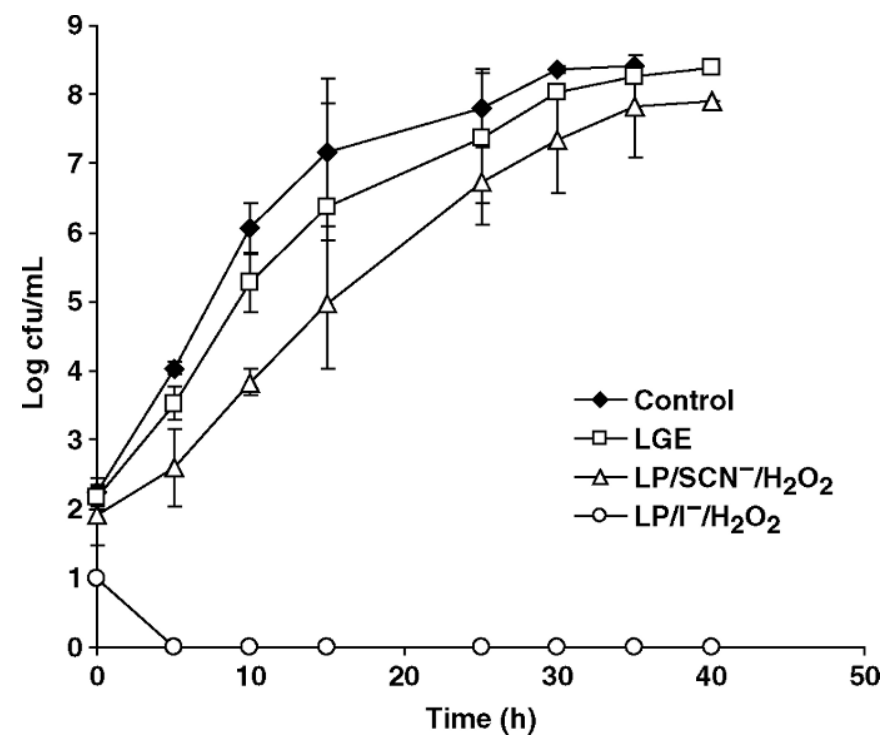

Figure 2. The antimicrobial effects of the different lactoperoxidase (LP) systems against Staphylococcus aureus in whole UHT milk. Error bars show the range of data from 2 separate experiments (detection limit $=1 \log \mathrm{cfu} / \mathrm{mL}$ ). Systems: $\mathrm{LGE}=\mathrm{LP}+$ garlic extract + ethanol; $\mathrm{LP} / \mathrm{SCN}^{-} / \mathrm{H}_{2} \mathrm{O}_{2}=\mathrm{LP}+$ thiocyanate + hydrogen peroxide; $\mathrm{LP} /$ $\mathrm{I}^{-} / \mathrm{H}_{2} \mathrm{O}_{2}=\mathrm{LP}+$ iodide + hydrogen peroxide. was achieved after $5 \mathrm{~h}$ of incubation. The antimicrobial activity was powerful enough to maintain the counts below detection limit for up to $14 \mathrm{~d}$ (data not shown), which suggests complete inactivation of the bacteria. The $\mathrm{LP}+\mathrm{GE}+\mathrm{E}$ system resulted in a small retardation in the bacterial growth. The $\mathrm{LP}+\mathrm{SCN}^{-}+\mathrm{H}_{2} \mathrm{O}_{2}$ system produced definite growth retardation and extended the lag phase by $5 \mathrm{~h}$ before the bacteria recovered and resumed logarithmic growth. The increase in lag resulted in an apparent increase in the bacterial generation time and so enhanced KQ by about $10 \mathrm{~h}$ (Table 1 ). The $\mathrm{LP}+\mathrm{I}^{-}$ $+\mathrm{H}_{2} \mathrm{O}_{2}$ activated sample was of acceptable quality up to the end of the experiment as demonstrated by the $\mathrm{KQ}$ results (Table 1), whereas the $\mathrm{LP}+\mathrm{GE}+\mathrm{E}$ sample had an extended KQ of $5 \mathrm{~h}$.

The growth and survival of $B$. cereus cells (Figure 3 ) gave generally similar results to Staph. aureus and $P$. aeruginosa. The $\mathrm{LP}+\mathrm{I}^{-}+\mathrm{H}_{2} \mathrm{O}_{2}$ system resulted in similar bactericidal action against $B$. cereus as with other strains. The counts were below detection limits within $10 \mathrm{~h}$ of incubation and the level was maintained up to the end of the experiment. The $\mathrm{LP}+\mathrm{SCN}^{-}+\mathrm{H}_{2} \mathrm{O}_{2}$ system prolonged the lag phase by $10 \mathrm{~h}$, but this was then followed by the normal bacterial growth rate. There was no pause in growth due to $\mathrm{LP}+\mathrm{GE}+\mathrm{E}$ treatment; however, there was some growth retardation. This is supported by the KQ (Table 1), which was greater for the $\mathrm{LP}+\mathrm{GE}+\mathrm{E}$ treated sample than the control sample but lower than the $\mathrm{LP}+\mathrm{SCN}^{-}+\mathrm{H}_{2} \mathrm{O}_{2}$ and $\mathrm{LP}+\mathrm{I}^{-}+\mathrm{H}_{2} \mathrm{O}_{2}$ treated samples.

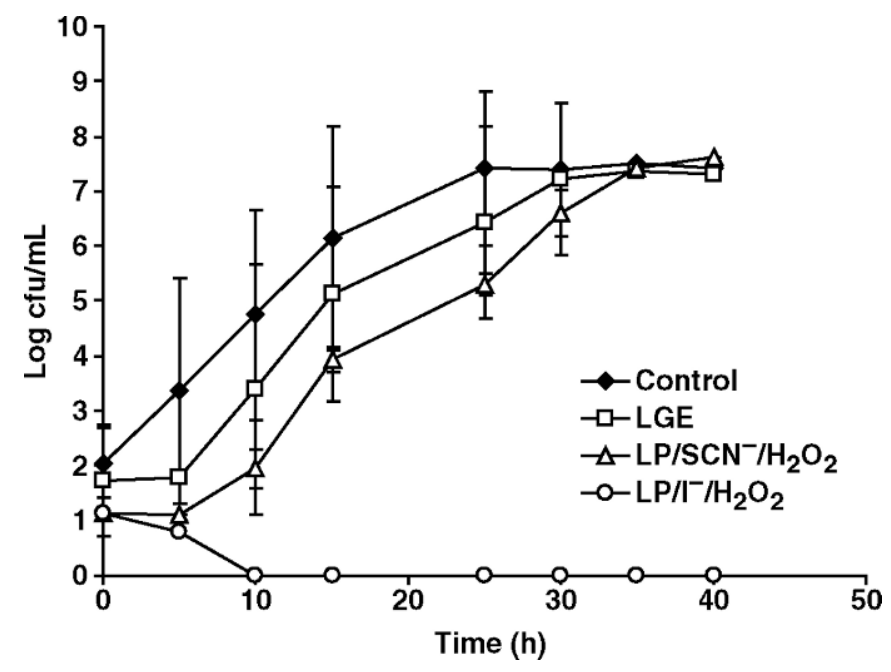

Figure 3. The antimicrobial effects of the different lactoperoxidase (LP) systems against Bacillus cereus in whole UHT milk. Error bars show the range of data from 2 separate experiments (detection limit = $1 \mathrm{log} \mathrm{cfu} / \mathrm{mL})$. Systems: LGE $=\mathrm{LP}+$ garlic extract + ethanol; LP/ $\mathrm{SCN}^{-} / \mathrm{H}_{2} \mathrm{O}_{2}=\mathrm{LP}+$ thiocyanate + hydrogen peroxide; $\mathrm{LP} / \mathrm{I}^{-} / \mathrm{H}_{2} \mathrm{O}_{2}=$ $\mathrm{LP}+$ iodide + hydrogen peroxide. 


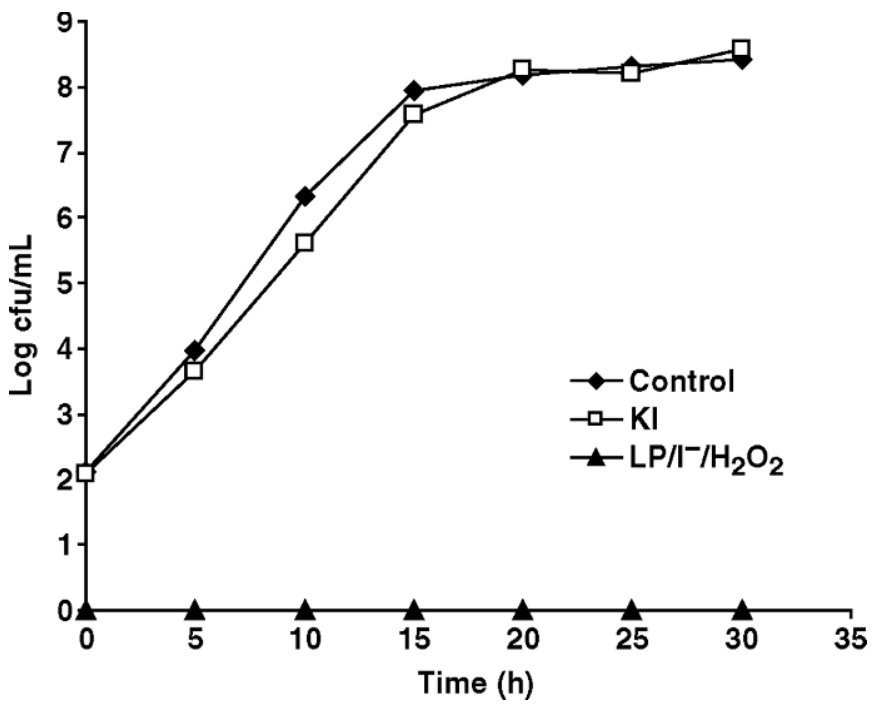

Figure 4. The antimicrobial effects of iodide (KI; $7 \mathrm{mg} / \mathrm{kg}$ ) alone, and in the presence of $\mathrm{H}_{2} \mathrm{O}_{2}(80 \mathrm{mg} / \mathrm{kg})$ and lactoperoxidase $\left(\mathrm{LP} / \mathrm{I}^{-} /\right.$ $\mathrm{H}_{2} \mathrm{O}_{2}$ ) against Staphylococcus aureus (detection limit $=1 \log \mathrm{cfu} / \mathrm{mL}$ ).

To eliminate the possibility that $\mathrm{I}^{-}$alone gave rise to the bactericidal effect and $\mathrm{H}_{2} \mathrm{O}_{2}$ alone to the bacteriostatic effect on the population, the antimicrobial effects of individual substrates of the LP systems against Staph. aureus at the same concentrations as used in the LP systems were investigated. Figure 4 shows that $\mathrm{I}^{-}$alone had no effect on bacterial growth and there was no effect on the $\mathrm{KQ}$ of the milk. Although $\mathrm{H}_{2} \mathrm{O}_{2}$ exerted some antibacterial effect (Figure 5), the $\mathrm{LP}+\mathrm{SCN}^{-}+\mathrm{H}_{2} \mathrm{O}_{2}$ system was more effective than $\mathrm{H}_{2} \mathrm{O}_{2}$ alone, and resulted in better $\mathrm{KQ}$ (35 to $40 \mathrm{~h}$ for $\mathrm{LP}+\mathrm{SCN}^{-}+\mathrm{H}_{2} \mathrm{O}_{2} ; 25$ to $30 \mathrm{~h}$ for $\mathrm{H}_{2} \mathrm{O}_{2}$ alone). These results indicate that LP-catalyzed oxidation of $\mathrm{SCN}^{-}$and $\mathrm{I}^{-}$, respectively, were responsible for the bacteriostatic and bactericidal effects exerted against the test strain population.

The $\mathrm{LP}+\mathrm{I}^{-}+\mathrm{H}_{2} \mathrm{O}_{2}$ system with or without $\mathrm{SCN}^{-}$at a greater microbial load (Figure 6) showed variation in susceptibility of Staph. aureus to the LP system activated with either $\mathrm{I}^{-}$or $\mathrm{SCN}^{-}$or combinations of both in different ratios. The $\mathrm{LP}+\mathrm{I}^{-}+\mathrm{H}_{2} \mathrm{O}_{2}$ system displayed similar bactericidal activity against Staph. aureus at a greater microbial load (5 log cycles) as was the case with a lower microbial load (2 log; Figure 2). However, complete inactivation was achieved after a 15 -h incubation compared with a $\leq 5$-h incubation time (Figure 2) with a lower initial cell density. The bacteriocidal effect of the $\mathrm{LP}+\mathrm{I}^{-}+\mathrm{H}_{2} \mathrm{O}_{2}$ system was reduced in the presence of $\mathrm{SCN}^{-}$and its effectiveness depended on the relative amount of $\mathrm{SCN}^{-}$to $\mathrm{I}^{-}$. The bacteriocidal effect and growth inhibition was greater with the $\mathrm{LP}+\mathrm{I}^{-}+\mathrm{H}_{2} \mathrm{O}_{2}$ system with a $1: 2 \mathrm{SCN}^{-}: \mathrm{I}^{-}$ratio than with a $1: 1 \mathrm{SCN}^{-}$

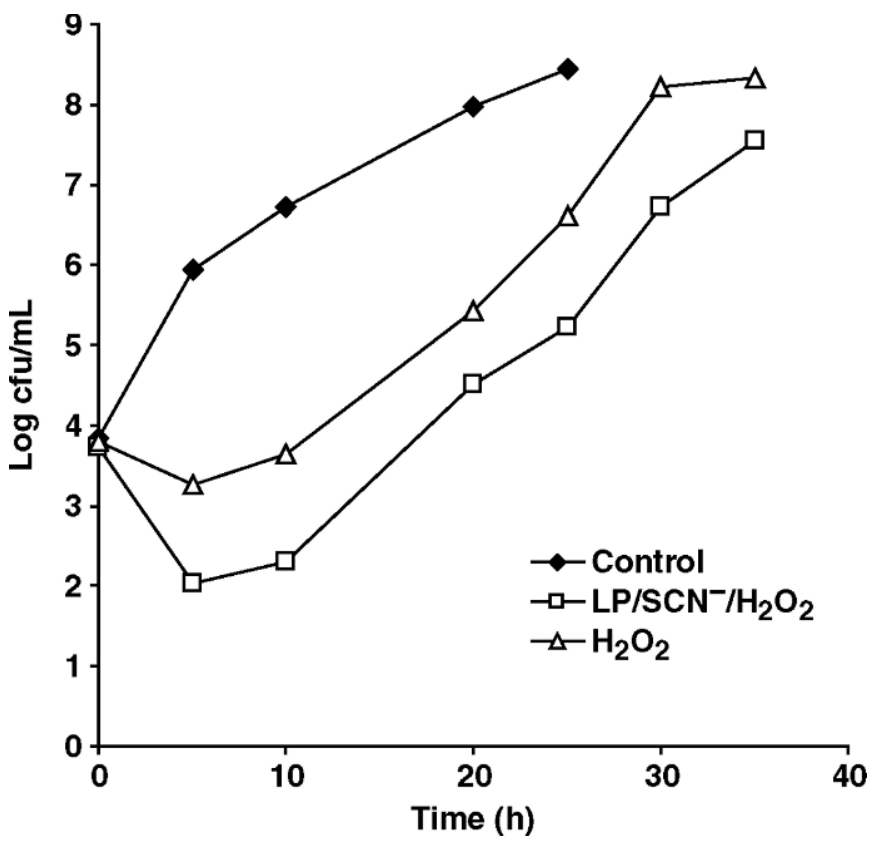

Figure 5. The antimicrobial effects of $\mathrm{H}_{2} \mathrm{O}_{2}(80 \mathrm{mg} / \mathrm{kg})$ alone and in the presence of lactoperoxidase and $\mathrm{SCN}^{-}\left(\mathrm{LP} / \mathrm{SCN}^{-} / \mathrm{H}_{2} \mathrm{O}_{2} ; 7 \mathrm{mg} /\right.$ $\mathrm{kg}$ ) against Staphylococcus aureus in whole UHT milk.

: $\mathrm{I}^{-}$ratio. The $\mathrm{KQ}$ also decreased with increasing concentration of $\mathrm{SCN}^{-}$in the $\mathrm{LP}+\mathrm{I}^{-}+\mathrm{H}_{2} \mathrm{O}_{2}$ system $(>80 \mathrm{~h}$ with $\mathrm{I}^{-}$alone; $70 \mathrm{~h}$ with $1: 2 \mathrm{SCN}^{-}: \mathrm{I}^{-}$ratio; $45 \mathrm{~h}$ with $1: 1 \mathrm{SCN}^{-}$ : $\mathrm{I}^{-}$ratio; $25 \mathrm{~h}$ with $\mathrm{SCN}^{-}$alone). A similar trend was observed when a mixed inoculum of Staph. aureus, B.

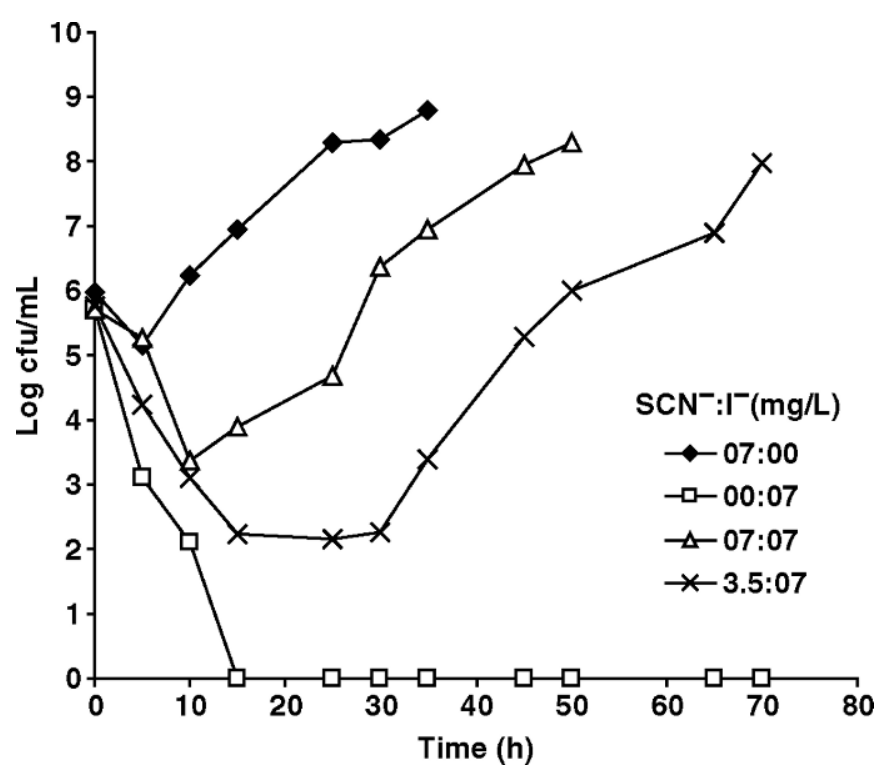

Figure 6. Susceptibility of Staphylococcus aureus to the hypoiodite-generating lactoperoxidase (LP) system with different combination levels of $\mathrm{SCN}^{-}: \mathrm{I}^{-}$(detection limit $=1 \log \mathrm{cfu} / \mathrm{mL}$ ). 


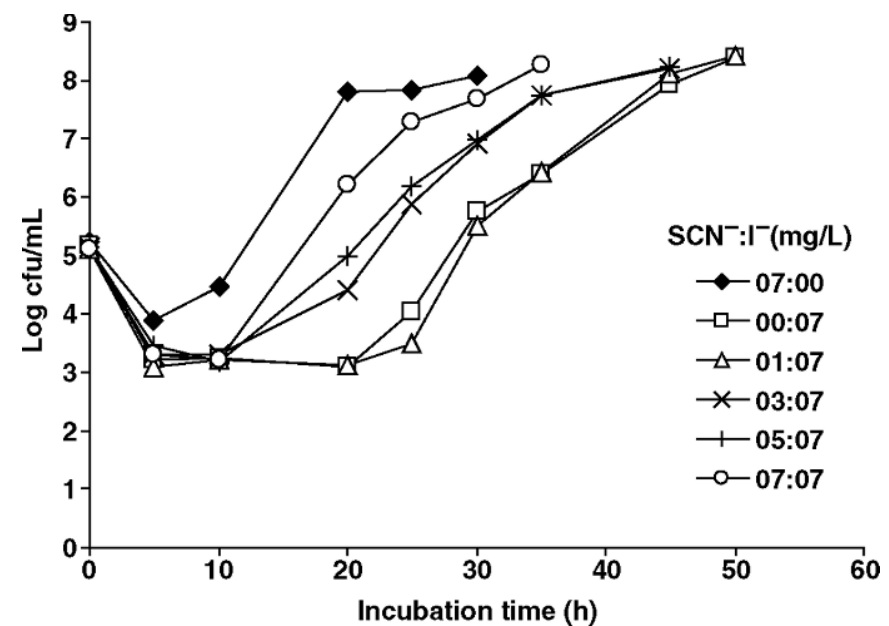

Figure 7. The antimicrobial effects of lactoperoxidase system activated using different combination levels of $\mathrm{SCN}^{-}: \mathrm{I}^{-}$in whole UHT milk inoculated with a high initial level $\left(10^{5}\right)$ of mixed culture (Staphylococcus aureus, Bacillus cereus, and Pseudomonas aeruginosa).

cereus, and $P$. aeruginosa and more combination levels of $\mathrm{SCN}^{-}: \mathrm{I}^{-}$were used (Figure 7). The least growth inhibition was observed for the $\mathrm{LP}+\mathrm{SCN}^{-}+\mathrm{H}_{2} \mathrm{O}_{2}$ system, whereas the greatest growth inhibition was recorded for the $\mathrm{LP}+\mathrm{I}^{-}+\mathrm{H}_{2} \mathrm{O}_{2}$ system and the $\mathrm{LP}+\mathrm{I}^{-}+\mathrm{SCN}^{-}+\mathrm{H}_{2} \mathrm{O}_{2}$ system with a $1: 7 \mathrm{SCN}^{-}: \mathrm{I}^{-}$ratio, with intermediate ratios following the expected trend. The $\mathrm{KQ}$ results followed a similar trend with 20 to $30 \mathrm{~h}$ for $\mathrm{SCN}^{-}$alone to 50 to $55 \mathrm{~h}_{\text {for }} \mathrm{I}^{-}$alone and intermediate $\mathrm{KQ}$ values for intermediate ratios. The $\mathrm{LP}+\mathrm{I}^{-}+\mathrm{H}_{2} \mathrm{O}_{2}$ system with or without $\mathrm{SCN}^{-}$, however, failed to show such an effective bacteriocidal effect (as had been demonstrated earlier with individual cultures) against the mixed cultures inoculated at 5 log cycle cell density. The bacterial survival rate was greater under these experimental conditions, which led to a shorter $\mathrm{KQ}$ implying a reduction in the system's toxicity. The quantitative effect of microbial load was further investigated by carrying out another set of experiments using a lower microbial load (2 log cycles) of the same strains (Figure 8). At this cell density, the $\mathrm{LP}^{-}+\mathrm{H}_{2} \mathrm{O}_{2}$ system with or without $\mathrm{SCN}^{-}$ replicated the bactericidal effect and enhanced the $\mathrm{KQ}$ ( $25 \mathrm{~h}$ with $\mathrm{SCN}^{-}$alone; $>85 \mathrm{~h}$ at all levels of $\mathrm{I}^{-}$), which suggests that the lethality of the LP systems varies among strains and decreases with increasing microbial load.

A final experiment investigated the preservation of raw milk incubated at $30^{\circ} \mathrm{C}$ with $\mathrm{LP}+\mathrm{I}^{-}+\mathrm{H}_{2} \mathrm{O}_{2}$ and $\mathrm{LP}+\mathrm{SCN}^{-}+\mathrm{H}_{2} \mathrm{O}_{2}$ systems (Figure 9). Although there was immediate microbial growth for the control sample and a 5 -h extension in lag phase for the $\mathrm{LP}+\mathrm{SCN}^{-}+\mathrm{H}_{2} \mathrm{O}_{2}$ sample, the $\mathrm{LP}+\mathrm{I}^{-}+\mathrm{H}_{2} \mathrm{O}_{2}$ sample demonstrated a partial lethal effect and a more extended lag phase for the

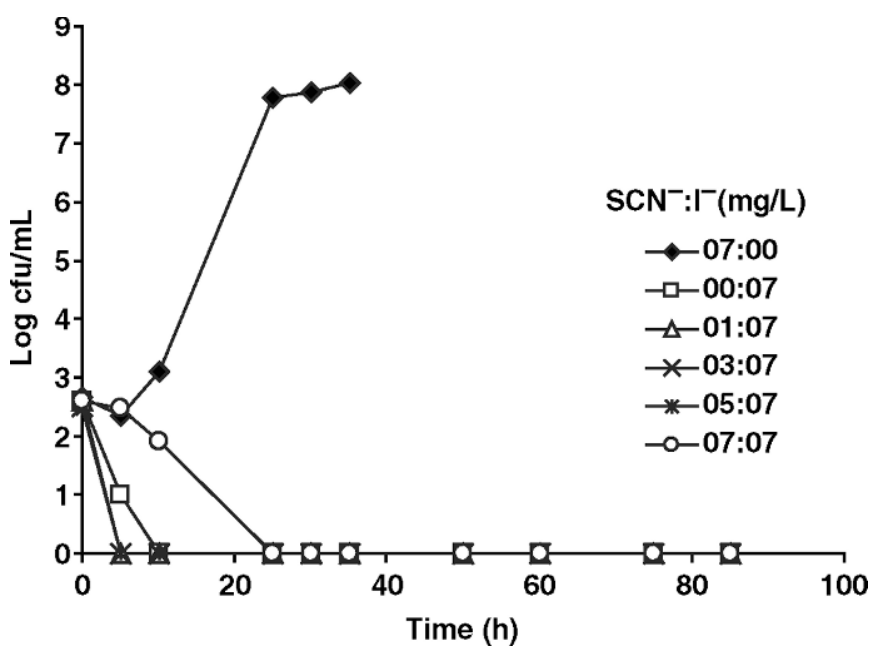

Figure 8. The antimicrobial effects of lactoperoxidase system activated using different combination levels of $\mathrm{SCN}^{-}: \mathrm{I}^{-}$in whole UHT milk inoculated with a low initial level $\left(2 \log _{10}\right)$ of mixed bacterial strains (Staphylococcus aureus, Bacillus cereus, and Pseudomonas aeruginosa) (detection limit $=1 \log \mathrm{cfu} / \mathrm{mL}$ ).

first $10 \mathrm{~h}$ before resuming the normal growth. The KQ results showed better preservative effects of the $\mathrm{LP}+\mathrm{I}^{-}$ $+\mathrm{H}_{2} \mathrm{O}_{2}$ system ( 35 to $45 \mathrm{~h}$ ) compared with the $\mathrm{LP}+\mathrm{SCN}^{-}$ $+\mathrm{H}_{2} \mathrm{O}_{2}$ system (30 to $40 \mathrm{~h}$ ) or the control raw milk (15 to $25 \mathrm{~h}$ ).

\section{DISCUSSION}

\section{Antimicrobial Effects of the LP Systems}

The 3 combinations of LP-s substrates produced wide variations in antimicrobial effects of the LP-s against

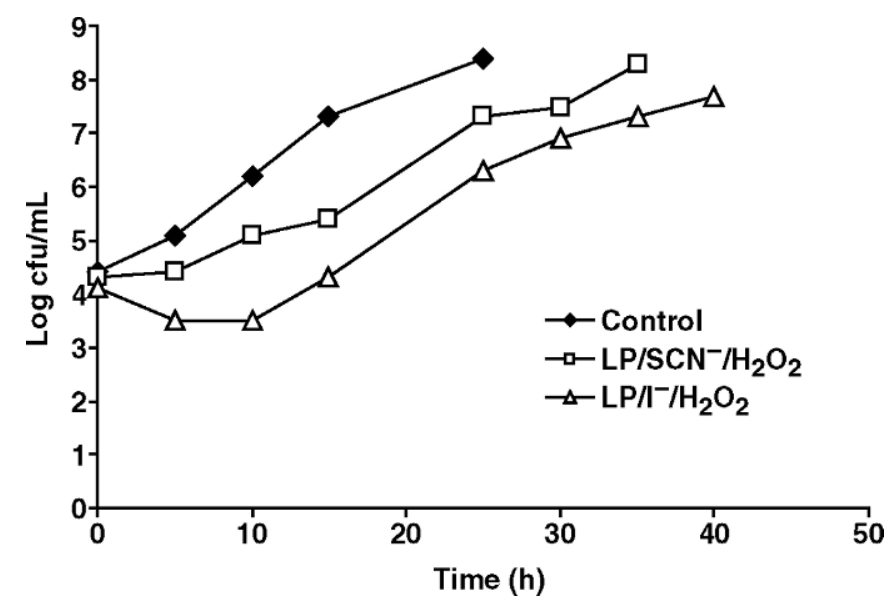

Figure 9. The antimicrobial effects of lactoperoxidase + thiocyanate + hydrogen peroxide $\left(\mathrm{LP} / \mathrm{SCN}^{-} / \mathrm{H}_{2} \mathrm{O}_{2}\right)$ and lactoperoxidase + iodide + hydrogen peroxide $\left(\mathrm{LP} / \mathrm{I}^{-} / \mathrm{H}_{2} \mathrm{O}_{2}\right)$ in raw milk incubated at $30^{\circ} \mathrm{C}$. 
Staph. aureus, B. cereus, and P. aeruginosa. The wide variations in the antimicrobial activity among the LPs may be correlated with the stability of the oxidizing agent(s) produced or their ability to penetrate microbial membranes (Thomas, 1985). Barraquio et al. (1994) related the degree of inhibition to the strength of the interaction of the antimicrobial products and free $\mathrm{SH}$ groups of vital enzymes in the bacterial cell wall. It has been established that the oxidizing agents formed from halides and $\mathrm{SCN}^{-}$differ in oxidation potential, stability, and solubility (Thomas, 1985). The higher charge density of $\mathrm{I}^{-}$compared with $\mathrm{SCN}^{-}$leads to the formation of more stable compounds between $\mathrm{I}^{-}$and $\mathrm{SH}$ groups of bacterial enzymes, and hence the greater bacteriocidal effect of the oxidation products of $\mathrm{I}^{-}$compared with those of $\mathrm{SCN}^{-}$(De Wit and Van Hooydonk, 1996). They also described the bacteriocidal characteristics of the iodide system against a mixture of Micrococcus, Staphylococcus, Listeria, and B. cereus as reminiscent of the irreversible oxidation of $\mathrm{SH}$ groups by $\mathrm{I}^{-}$-induced $\mathrm{LP}$ effects. Although the antimicrobial activity of $\mathrm{LP}+\mathrm{SCN}^{-}$ $+\mathrm{H}_{2} \mathrm{O}_{2}$ is more dependent on temperature and $\mathrm{pH}, \mathrm{LP}+{ }^{-}$ $+\mathrm{H}_{2} \mathrm{O}_{2}$ promotes killing independently of these factors (Bosch et al., 2000). It is probable that the performance of the $\mathrm{LP}+\mathrm{GE}+\mathrm{E}$ system is also influenced by similar factors. The $\mathrm{LP}+\mathrm{GE}+\mathrm{E}$ system was much the least effective among the $3 \mathrm{LP}$ systems and also imparted a strong garlic smell to milk, which adds to the limitations of this system.

The lethal effect of $\mathrm{LP}+\mathrm{I}^{-}+\mathrm{H}_{2} \mathrm{O}_{2}$ system is consistent with previous findings that reported $0 \%$ survival rates of both Escherichia coli (Klebanoff, 1967) and Candida albicans (Majerus and Courtois, 1992) in the activated $\mathrm{LP}+\mathrm{I}^{-}+\mathrm{H}_{2} \mathrm{O}_{2}$ system in acetate buffer $(\mathrm{pH} 5)$ and phosphate buffer ( $\mathrm{pH} 7.4$ ), respectively. The variation in the incubation time necessary for the complete inactivation to occur on exposure to $\mathrm{LP}+\mathrm{I}^{-}+\mathrm{H}_{2} \mathrm{O}_{2}$ reflects the possible variation in sensitivity among strains. This may depend on the cell-wall structure and inhibitory compounds generated by the organism in question (Korhonen, 2004 ), or on the susceptibility of the primary target enzyme to the LP system (Shin et al., 2001). Whereas complete inactivation was rapid in the case of $P$. aeruginosa, it was slower against B. cereus and Staph. aureus, which suggests that the system is more effective against gram-negative bacteria than gram-positive bacteria. This is in contrast to the findings of Revol-Junelles et al. (2001), who concluded that activation with $\mathrm{I}^{-}$or $\mathrm{IO}^{3-}$ was effective against Staph. aureus, but ineffective against 2 gram-negative strains (Pseudomonas fluorescens and $E$. coli). An initial reduction in microbial counts observed for $\mathrm{LP}+\mathrm{SCN}^{-}+\mathrm{H}_{2} \mathrm{O}_{2}$ suggests that the system acts bacteriocidally with an overall bacteriostatic effect on the population. The antibacterial effects of $\mathrm{LP}+\mathrm{SCN}^{-}+\mathrm{H}_{2} \mathrm{O}_{2}$ coupled with a reduction in colony count at the early stage has been reported previously in both buffalo and cow milk (Björck et al., 1979; Ewais et al., 1985; Chakraborty et al., 1986). Kamau et al. (1990) described the decrease in colony count of both Listeria monocytogenes and Staph. aureus in milk during the initial 0 to $2 \mathrm{~h}$ as the killing of a small fraction of the bacteria, and attributed it to the killing effect of short-lived products of the LP-s, which are more bactericidal than $\mathrm{OSCN}^{-}$. However, it should also be emphasized that the antimicrobial effect of LP system on any particular organism depends on the reaction conditions (Pruitt and Reiter, 1985).

The complete inhibition of $P$. aeruginosa by $\mathrm{LP}+\mathrm{SCN}^{-}$ $+\mathrm{H}_{2} \mathrm{O}_{2}$ and its recovery appears to suggest a complete inhibition of respiration without loss of viability as reported in earlier studies (Thomas and Aune, 1978), although there could be other explanations including adaptation of a small number of survivors, or the presence of resistant mutants that survive and grow. It also confirms the findings of Bosch et al. (2000) who demonstrated complete inhibition of $P$. aeruginosa in the presence or absence of iodide. Incorporation of $\mathrm{SCN}^{-}$into $\mathrm{SH}$ groups of bacteria effectively removes the reacted SH groups from a functional role such as respiration and glycolysis and may result in cessation of growth (Mickelson, 1979). The complete inhibition observed for $P$. aeruginosa but not for B. cereus and Staph. aureus similarly suggests it being more effective against gramnegative than gram-positive bacteria. The $\mathrm{LP}+\mathrm{GE}+\mathrm{E}$ system was barely effective against $P$. aeruginosa, but had a slight effect against gram-positive bacteria, $B$. cereus and Staph. aureus.

The failure of $\mathrm{I}^{-}$alone to replicate the lethal effects of $\mathrm{LP}+\mathrm{I}^{-}+\mathrm{H}_{2} \mathrm{O}_{2}$ or exert any antimicrobial effect suggests that the resultant bactericidal effect was not just due to $\mathrm{I}^{-}$, but rather the complete $\mathrm{LP}+\mathrm{I}^{-}+\mathrm{H}_{2} \mathrm{O}_{2}$ system. It also appears to confirm the reliance of the antibacterial effect of $\mathrm{I}^{-}$on intermediate oxidation products (HOI, $\mathrm{OI}^{-}$). Identical findings were reported by (Klebanoff, 1968), who demonstrated lack of effect due to $\mathrm{I}^{-}$alone at $0.01 \mu M$ against Lactobacillus acidophilus in acetate buffer ( $\mathrm{pH} 5)$, which reinforces the view that the antibacterial effect of the $\mathrm{LP}+\mathrm{I}^{-}+\mathrm{H}_{2} \mathrm{O}_{2}$ system is due to the conversion of iodide by oxidation to a strong antibacterial agent.

The greater antimicrobial activity observed for $\mathrm{LP}+\mathrm{SCN}^{-}+\mathrm{H}_{2} \mathrm{O}_{2}$ compared with $\mathrm{H}_{2} \mathrm{O}_{2}$ alone implies that the amount of $\mathrm{H}_{2} \mathrm{O}_{2}$ used for activation was still adequate to function as a component of the LP system. Excessive amounts of $\mathrm{H}_{2} \mathrm{O}_{2}$ inactivate the enzyme, and $\mathrm{H}_{2} \mathrm{O}_{2}$ on its own is an effective antimicrobial agent when applied at a much greater concentration $(300 \mathrm{ppm}$; FAO/WHO, 1991), although these levels of addition are 
not generally permissible. Greater $\mathrm{H}_{2} \mathrm{O}_{2}$ concentrations or the presence of catalysts such as LP overcomes the kinetic barrier to $\mathrm{H}_{2} \mathrm{O}_{2}$ toxicity (Thomas, 1985).

\section{Single or Mixed Cultures in the $\mathrm{LP}-\mathrm{H}_{2} \mathrm{O}_{2}$ plus SCN $\mathrm{SN}^{-}$or or Both}

The effectiveness of the $\mathrm{LP}+\mathrm{I}^{-}+\mathrm{H}_{2} \mathrm{O}_{2}$ system at a greater initial microbial load, as in the case of poor quality milk, and its performance in the presence of $\mathrm{SCN}^{-}$(which occurs naturally in milk at 1 to $15 \mathrm{mg} / \mathrm{L}$ ) was tested using greater counts of Staph. aureus and different combination levels of $\mathrm{SCN}^{-} / \mathrm{I}^{-}$. The decrease in the bactericidal effect of $\mathrm{LP}+\mathrm{I}^{-}+\mathrm{H}_{2} \mathrm{O}_{2}$ with increasing $\mathrm{SCN}^{-}$concentration suggests an effective competition of $\mathrm{SCN}^{-}$with $\mathrm{I}^{-}$for LP-catalyzed oxidation (Thomas, 1985). Majerus and Courtois (1992) observed a more lethal effect of hypoiodite produced by the LP system in saliva against Candida albicans ATCC 10231 in a group of nonsmokers with salivary $\mathrm{SCN}^{-}$concentrations of $1.24 \pm 0.28 \mathrm{mM}$ compared with a group of smokers with concentrations of $2.63 \pm 0.25 \mathrm{mM}$. Klebanoff $(1967,1968)$ demonstrated the decrease in the bactericidal effect of myeloperoxidase-iodide- $\mathrm{H}_{2} \mathrm{O}_{2}$ against $E$. coli in acetate buffer ( $\mathrm{pH}$ 5.0) with increasing $\mathrm{SCN}^{-}$ concentration. It appears that, rather than contributing to the antibacterial action, incorporation of $\mathrm{SCN}^{-}$interferes and lowers the bactericidal effects of the iodide system. The effect is probably due to the preferential interaction of $\mathrm{SCN}^{-}$with compound I (reaction product of $\mathrm{LP}$ with $\mathrm{H}_{2} \mathrm{O}_{2}$ ), resulting in limited oxidation of $\mathrm{I}^{-}$and hence limited production of antimicrobial compounds. This is supported by the hierarchy of reduction potential (Furtmüller et al., 2002), which demonstrates the relatively greater reactivity of $\mathrm{SCN}^{-}$with compound I with a rate constant of $2.0 \times 10^{8} \mathrm{~mol}^{-1} \mathrm{~s}^{-1}$ compared with $\mathrm{I}^{-}$with compound $\mathrm{I}$ with a rate constant of (1.2 \pm $0.4) \times 10^{8} \mathrm{~mol}^{-1} \mathrm{~s}^{-1}$. These results emphasize the existence of competition for peroxidase and the importance of $\mathrm{I}^{-}: \mathrm{SCN}^{-}$ratio for the performance of the $\mathrm{LP}+\mathrm{I}^{-}+\mathrm{H}_{2} \mathrm{O}_{2}$ system (Majerus and Courtois, 1992).

The investigation of the quantitative effect of microbial load on the performance of the $\mathrm{LP}+\mathrm{I}^{-}+\mathrm{H}_{2} \mathrm{O}_{2}$ system with or without $\mathrm{SCN}^{-}$demonstrated the variation in the lethality of the system with changes in cell density of both single and mixed strains. The system appeared to be more lethal at low cell density as reflected by either a shorter incubation time for complete inactivation to occur or reduced survival rate of the test strains, which is probably a reflection of the fact that there are more cells to kill at greater cell densities. Wolfson and Sumner (1994) demonstrated the dependency of the bacteriocidal effect on the initial inoculum of Salmonella typhimurium in trypticase soy broth. The $\mathrm{LP}+\mathrm{SCN}^{-}$
$+\mathrm{H}_{2} \mathrm{O}_{2}$ system was bacteriocidal to an inoculum level of $10^{2} \mathrm{cfu} / \mathrm{mL}$ at $37^{\circ} \mathrm{C}$ but bacteriostatic to the population at inoculum levels of $10^{6}$ to $10^{7} \mathrm{cfu} / \mathrm{mL}$. The decrease in cell density seemed to increase the amount of the antimicrobial agent to which each cell is exposed and raised the plateau levels of bactericidal action (Thomas and Aune, 1978). The difference in inactivation of Staph. aureus and mixed cultures at almost the same cell density also suggests that the lethality of the LP systems varies among strains.

\section{Preservation of Raw Milk with $\mathrm{LP}+\mathrm{I}^{-}+\mathrm{H}_{2} \mathrm{O}_{2}$ and $\mathrm{LP}+\mathrm{SCN}^{-}+\mathrm{H}_{2} \mathrm{O}_{2}$ Systems}

The $\mathrm{LP}+\mathrm{I}^{-}+\mathrm{H}_{2} \mathrm{O}_{2}$ system showed better preservative effects in raw milk compared with the $\mathrm{LP}+\mathrm{SCN}^{-}+\mathrm{H}_{2} \mathrm{O}_{2}$ system, implying that $\mathrm{H}_{2} \mathrm{O}_{2}$ catalyzed oxidation of $\mathrm{I}^{-}$ results in the formation of more effective antimicrobial compounds than $\mathrm{H}_{2} \mathrm{O}_{2}$ catalyzed oxidation of $\mathrm{SCN}^{-}$. Both LP systems showed weaker antimicrobial activity in raw milk than in inoculated UHT milk. This could be because the resident microflora in the raw milk was more resistant than the 3 bacteria used as inoculum, although this was not tested here. The results are consistent with those obtained for field trials carried out in tropical conditions in Tanzania using $15: 15 \mathrm{mg} / \mathrm{L}$ of $\mathrm{I}^{-}: \mathrm{H}_{2} \mathrm{O}_{2}$ (unpublished data). They also suggest that oxidation of only a small amount of $\mathrm{I}^{-}$has a huge impact on the KQ of raw milk. The interference with $\mathrm{SCN}^{-}$ reduces the amount of $\mathrm{I}^{-}$oxidized in the LP system to yield antimicrobial compounds. However, because of the relatively lower concentration of iodide in dairy milk (220 $\pm 120 \mu \mathrm{g} / \mathrm{L}$; Lacroix and Wong, 1980, and 9.6 to $382 \mu \mathrm{g} / \mathrm{L}$; Kirk et al., 2005) compared with $\mathrm{SCN}^{-}(1$ to $15 \mathrm{mg} / \mathrm{L}$; Reiter and Harnulv, 1984; Wolfson and Sumner, 1993; De Wit and Van Hooydonk, 1996, and 4 to $59 \mathrm{mg} / \mathrm{L}$; Korhonen, 1973), it is unlikely that the $\mathrm{LP}+\mathrm{I}^{-}+\mathrm{H}_{2} \mathrm{O}_{2}$ system would exert any antimicrobial effect without reactivation. Iodine in the milk of ruminants exists primarily in the iodide form (Lacroix and Wong, 1980) and varies widely: $140 \mathrm{ng} / \mathrm{L}$ (Swanson et al., 1990) and 30 to $3,484 \mu \mathrm{g} / \mathrm{kg}$ (Bruhn and Franke, 1985). Iodine is important in human nutrition; however, excess as well as deficiency is of concern (Lacroix and Wong, 1980). Its deficiency may lead to retardation of fetus development, death, or weak neonates with hyperplastic thyroid goiter, whereas excessive amounts may lead to thyrotoxicosis or hypersensitivity in the general population (Paulíková et al., 2002). It is thus important to investigate the implication of using iodide as an LP-s substrate on the health of the milk-drinking population and on the quality of milk and milk products. 


\section{CONCLUSIONS}

The study generally confirms the dependency of the antibacterial effects of LP systems on substrate composition, microbial composition, and microbial load. The $\mathrm{H}_{2} \mathrm{O}_{2}$-dependent oxidation of $\mathrm{I}^{-}$provides the most effective system compared with $\mathrm{SCN}^{-}$or garlic extract as an electron donor. The negative synergistic effects of $\mathrm{I}^{-}$ and $\mathrm{SCN}^{-}$on the performance of LP system demonstrated in this study imply the dependence of the levels of use of $\mathrm{I}^{-}$for the activation of the LP system on the natural $\mathrm{SCN}^{-}$concentration in milk. However, despite the greater levels of $\mathrm{SCN}^{-}$in milk and its interference with $\mathrm{LP}+\mathrm{I}^{-}+\mathrm{H}_{2} \mathrm{O}_{2}$, the latter is a more effective system in milk preservation than $\mathrm{LP}+\mathrm{SCN}^{-}+\mathrm{H}_{2} \mathrm{O}_{2}$. The current observation opens further avenues for the establishment of minimum and optimum levels of use of $\mathrm{I}^{-}$in the LP system, its health implications for milk consumers, and the general acceptability of $\mathrm{LP}+\mathrm{I}^{-}+\mathrm{H}_{2} \mathrm{O}_{2}$ to activate milk.

\section{REFERENCES}

Barraquio, V. L., L. E. Resubal, I. B. M. Bantoc, and E. N. Almazan. 1994. Preservation of raw milk with lactoperoxidase/hydrogen peroxide/thiocyanate system, hydrogen peroxide system and by refrigeration. Asia Life Sci. 3:1-10.

Barrett, N. E., A. S. Grandison, and M. J. Lewis. 1999. Contribution of the lactoperoxidase system to the keeping quality of pasteurized milk. J. Dairy Res. 66:73-80.

Björck, L., O. Claesson, and W. Schulthess. 1979. The lactoperoxidase/ thiocyanate/hydrogen peroxide system as a temporary preservative for raw milk in developing countries. Milchwissenschaft 34:726-729.

Bosch, E. H., H. Van Doorne, and S. De Vries. 2000. The lactoperoxidase system: The influence of iodide and the chemical and antimicrobial stability over the period of about 18 months. J. Appl. Microbiol. 89:215-224.

Bruhn, J. C., and A. A. Franke. 1985. Iodine in cows' milk produced in the USA in 1980-1981. J. Food Prot. 48:397-399.

Cailliez-Grimal, C., A. M. Revo-Juvenelles, M. Linder, and J. B. Milliere. 2002. Antimicrobial activity of the glucose/glucose-oxidase and the lactoperoxidase system $\left(\mathrm{SCN}^{-}\right)$modified by $\mathrm{I}^{-}$or $\mathrm{IO}_{3}{ }^{-}$ anion. Milchwissenschaft 57:656-660.

Chakraborty, B. K., S. S. Chaudry, K. A. Alex, G. Jacob, and G. J. Soni. 1986. Application of the lactoperoxidase system for preserving buffalo milk produced in Indian villages. Milchwissenschaft 41:16-19.

De Wit, J. N., and A. C. M. Van Hooydonk. 1996. Structure, functions and applications of lactoperoxidase in natural antimicrobial systems. Neth. Milk Dairy J. 50:227-244.

Ewais, S. M., A. S. Hefnawy, and A. El-Salam. 1985. Utilisation of lactoeproxidase system in preservation of raw milk under local condition. Egyptian J. Dairy Sci. 13:1-7.

FAO/WHO. 1991. Guidelines for the preservation of raw milk by use of the lactoperoxidase system. Report of joint FAO/WHO committee on food additives CAC/GL 13. FAO, Rome, Italy.

Furtmüller, P. G., W. Jantschko, G. Regelsberger, C. Jakopitsch, J. Arnhold, and C. Obinger. 2002. Reaction of lactoperoxidase compound I with halides and thiocyanate. Biochemistry 41:11895-11900.

Harding, F. 1995. Hygienic quality. Pages 40-59 in Milk Quality. F. Harding, ed. Blackie Academic and Professional, London, UK.
Jandal, J. M. 1998. Lactoperoxidase/garlic extract/ethanol system in the preservation of buffalo milk. Buffalo J. 1:95-101.

Kamau, D. N., S. Doores, and K. M. Pruitt. 1990. Antibacterial activity of the lactoperoxidase system against Listeria monocytogenes and Staphylococcus aureus in milk. J. Food Prot. 53:1010-1078.

Kirk, A. B., P. K. Martinelango, K. Tian, A. Dutta, E. E. Smith, and P. K. Dasgupta. 2005. Percholate and iodide in dairy and breast milk. Environ. Sci. Technol. 39:2011-2017.

Klebanoff, S. J. 1967. Iodination of bacteria: A bactericidal mechanism. J. Exp. Med. 126:1063-1078.

Klebanoff, S. J. 1968. Myeloperoxidase-halide-hydrogen peroxide antibacterial system. J. Bacteriol. 95:2131-2138.

Korhonen, H. 1973. Untersuchungen zur Bacterizidie der Milch Immunisierung del bovinen Milchdruse. Finnish J. Dairy Sci. 32:1-15.

Korhonen, H. 2004. The Lactoperoxidase system in mastitic milk. FAO Lactoperoxidase Expert Meeting, Cape Town, South Africa. $\mathrm{FAO} / \mathrm{WHO}$, Rome, Italy.

Lacroix, D. E., and N. P. Wong. 1980. Determination of iodide in milk using the iodide specific ion electrode and its application to market milk samples. J. Food Prot. 43:672-674.

Majerus, P. M. C., and P. A. P. Courtois. 1992. Susceptibility of Candida albicans to peroxide catalysed oxidation of thiocynate, iodide and bromide. J. Biol. Buccale 20:241-245.

Marks, N. E., A. S. Grandison, and M. J. Lewis. 2001. Challenge testing of the lactoperoxidase system in pasteurised milk. J. Appl. Microbiol. 91:735-741.

Mickelson, M. N. 1979. Antibacterial action of lactoperoxidase-thiocyanate-hydrogen peroxide on Streptococcus agalactiae. Appl. Environ. Microbiol. 38:821-826.

Paulíková, I., G. Kovác, J. Bíreś, Ś. Paulík, H. Seidel, and O. Nagy. 2002. Iodine toxicity in ruminants. Vet. Med. (Czech) 47:343-350.

Pruitt, K. M., and B. Reiter. 1985. Biochemistry of peroxidase system: Antimicrobial effects. Pages 143-178 in The Lactoperoxidase System: Chemistry and Biological Significance. K. M. Pruitt and J. Tenovuo, ed. Marcel Dekker Inc., New York, NY.

Reiter, B., and B. G. Harnulv. 1984. Lactoperoxidase antibacterial system: Natural occurrence, biological functions and practical applications. J. Food Prot. 47:724-732.

Revol-Junelles, A.-M., N. Boussouel, J.-P. Ramet, and J.-B. Milliere. 2001. Antibacterial activities of lactoperoxidase systems (LPS) modified by $\mathrm{I}^{-}$and $\mathrm{IO}_{3}{ }^{-}$anions. Milchwissenschaft 56:329-332.

Rossi, E. A., and J. S. De Oliveira. 1993-1994. Effect of thiocyanate concentration on the effectiveness of the lactoperoxidase system activated in raw milk. Aliment. Nutr. 5:49-56.

Shin, K., H. Hayasawa, and B. Lonnerdal. 2001. Inhibition of Escherichia coli respiratory enzymes by the lactoperoxidase-hydrogen peroxide-thiocyanate antimicrobial system. J. Appl. Microbiol. 90:489-493.

Siva, C. V., K. G. Upadhyay, and S. S. Sannabhadti. 1991. Lactoperoxidase/thiocyanate/ $\mathrm{H} 2 \mathrm{O} 2$ system, its uses and implication in manufacture of dairy products. Indian Dairyman 43:240-246.

Swanson, E. W., J. K. Miller, F. J. Mueller, C. S. Patton, J. A. Bacon, and N. Ramsey. 1990. Iodine in milk and meat of dairy cows fed different amounts of potassium iodide or ethylenediamine dihydroiodide. J. Dairy Sci. 73:398-405.

Thomas, E. L. 1985. Products of lactoperoxidase catalyzed oxidation of thiocyanate and halides. Pages 179-202 in The Lactoperoxidase System: Chemistry and Biological Significance. K. M. Pruitt and J. Tenovuo, ed. Marcel Dekker Inc., New York, NY.

Thomas, E. L., and T. M. Aune. 1978. Cofactor role of iodide in peroxidase antimicrobial action against Escherichia coli. Antimicrob. Agents Chemother. 13:1000-1005.

Wolfson, L. M., and S. S. Sumner. 1993. Antibacterial activity of the lactoperoxidase system: A review. J. Food Prot. 56:887-892.

Wolfson, L. M., and S. S. Sumner. 1994. Antibacterial activity of the lactoperoxidase system against Salmonella typhimirium in trypticase soy broth in the presence and absence of a heat treatment. J. Food Prot. 57:365-368. 